\title{
UNIVERSITY OF MISSOURI,
}

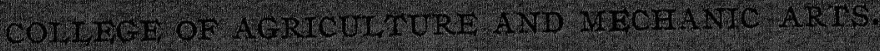

AGRICULTURAL EXPERIMENT STATION,

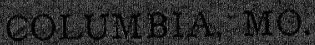

The Planting and Care of Shade Trees.

\author{
1.

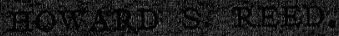

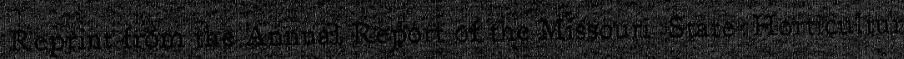

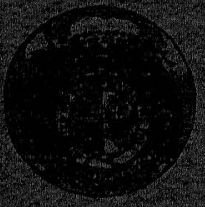



ON THE PLANTING AND CARE OF TREES FOR THE STREET AND LAWN.

(Howard S. Reed, Instructor in Botany in the University of Missouri, Columbia, Mo.)

A brief inspection of the streets of any of the cities or towns of this state will show many chances for improvement in the matter of ornamentation by shade trees, and many evidences of neglect and injury to those already planted.

The purpose of this bulletin is to give information on the proper method of planting and caring for shade trees on streets and lawns.

The value of shade trees should always be borne in mind by those parties laying out new streets or building lots. Trees not only add much to the attractiveness of the locality, but contribute materially to the health and comfort of the residents.

WHAT TO PLANT.

In selecting shade trees, experience has taught us that it is better to buy well-grown trees from a reliable nursery than to go to the woods and dig up natural seedlings. The nursery tree has been transplanted several times and has compact roots which are not injured by moving. The seedling from the forest, however, is often much injured by transplanting and by the time it has recovered, the nursery tree will be far ahead of it in size and vigor.

The tall, erect varieties of trees should be used for street planting, but the lower, spreading trees may be planted on lawns. Observation will show that certain kinds of trees succeed best in one part of the state and others in another locality. Some general recommendations, however, may be made as to the best trees to plant.

The oaks are rather slow growers and require plenty of light, but are exceedingly hardy. If transplanted when young from the nursery, the oaks make much more rapid and thrifty growth than when brought from the forest. 
The Bur-Oak (Mossy-cup oak, Over-cup oak) (Quercus macrocarpa. Michx.) is well adapted for a shade tree on the street or lawn. Mature specimens are frequently one hundred feet high and have a diameter at the base of three and a half feet. It thrives best in rich loam and is especially valuable for prairie planting.

The Chestnut Oak (Yellow Oak) (Quercus acuminata Michx; Sarg.) grows well in dry soil, especially along limestone ridges.

The Red Oak (Quercus rubra, L.) is the most rapid grower of all the oaks. It thrives on all soils except an undrained one.

Of the Hickories, most persons will prefer the Shagbark or Shellbark (Hicoria ovata Mill.; Britton). It comes into bearing when quite young and produces excellent, large nuts. The tree does not succeed well on poor, dry, or wet soils.

Elms, although natives of the swamp, grow well and remain perfectly thrifty in a great variety of soils. The White Elm (Ulmus Americana, L.) is one of the most valuable trees for street planting.

The Silver Maple (White Maple) (Acer saccharinum, L.) is extensively planted throughout the state as a shade tree. It grows rapidly, and, if properly pruned, makes a handsome tree; but it is often so seriously damaged by severe winds and hail-storms that it has little value as a shade tree. The trees should be pruned to form numerous small branches instead of a few large ones, as the latter are easily broken by severe winds. In many respects the Sttgar or Rock Maple (Acer saccharum, Marsh.) is more satisfactory than the white maple. It grows to a height of seventytive feet and forms a very compact top. It is a fairly rapid and persistent grower, and endures a moderate amount of shade. Storms and high winds do not damage this tree as they do the White Maple.

In localities where the soil is not too compact, one may plant the Lacusts. They grow rapidly when young, but need plenty of light. The Yellow (or Black) Locust (Robinia pseudacacia, L.) is more desirable for streets and lawns than the Honey Locust (Gleditsia triacantheos, L.) It is, however, subject to the attacts of a wood-destroying fungus (Polyporous rimosus $)^{1}$, which is more frequent on the older trees and detracts considerably from the value of the Locust as a shade tree.

The Catalpa (Catalpa speciosa, Warder) is a rapid growing tree which is widely planted in the west. The tree grows well in a great variety of soils, but does best on loamy clay. On the whole it cannot bc recommended for an ornamental tree because the older trees become very unsymmetrical unless given a great deal of light on all sides. Attention

1 Von Schrenk, H.: A disease of the Black Locust (Robinia pseudacacia). 12 Rep. Missouri Bot. Garden, 1901. 
may here be called to the economic value of the Catalpa; several railroad corporations are cultivating it to obtain timber for ties and poles.

White Ash (Frarinus Americana, L.) Cottonwood (Populus deltoides, Marsh), Basswood (Tilia americana, L.) and Black Walnut (Juglans nigra, L.) are trees which are suited to almost all parts of the State, and will give good results.

The evergreen coniferous trees are valuable for lawns, parks, drives, etc., and add much to the attractiveness of the home surroundings. The best effects are obtained by planting the large evergreens at the rear and sides of the grounds. Their clark green foliage forms a desirable background for the lighter colors of the deciduous trees.

The White Pine (Pinus strobus, L.) is a rapid grower and succeeds well on a variety of soils. The tree does not attain rapid growth until after the fifth or sixth year; from that time until the twentieth year it grows from one to two and one-half feet per year. A number of finc specimens of White Pine stand in the lawn of the Rollins homestead at Columbia. These trees were planted in 1855 by Col. J. H. Rollins. In I897 the largest was twenty-nine inches in diameter, breast high, and sixty-four feet nine inches in height.

The Norway Spruce (Picea excelsa. Link.) is adapted to a loamy soil, but should not be planted on extremely dry soils, for it is badly injured by drouth. It grows at first rather slowly, but about the tenth or twelfth year its height-growth becomes rapid, and it develops into a symmetrical, conical tree. This tree is well suited for hedges and windbreaks. For the latter purpose, plant two or three rows, eight feet apart, the trees in one row alternating with those in the next.

The Austrian (Black) Pine (Pinus Laricio, Poir. var. austriaca) is frost-hardy and not sensitive to drought. It likes a moderately deep, porous and fairly moist soil, which need not be fertile. The tree develops a straight stem with a dome-shaped crown; as a rule, the height cloes not exceed seventy-five feet.

Of the smaller evergreens, a few deserve mention.

The Red Juniper (Juniperus rirginiana, L.) is an important evergreen for prairie regions; it endures drought well. The branches are horizontal, close together, and feathered to the ground. In some regions it forms a tree forty or fifty feet high, but in this state it is frequently seen only in the form of a shrub.

The Irish Juniper (Juniperus communis Hibcrnica, Loddiges) forms a graceful, compact and slender pyramid attaining a height of six to fifteen feet.

The Arbor Vitae (White Cedar) (Thuya occidentalis, L.) is a rapid 
grower and is easily transplanted. It sticceeds well in any soil not too stiff.

THE TIME TO PLANT.

Trees should be planted when they are in a dormant state or just as they start into growth in the spring. Very hardy deciduous trees, such as the Elm, Cottonwood and Ash, can often be successfully moved in the fall, if the ground is moist at the time of removal, but great care must be taken to work the soil in compactly about the roots so that there will be no large air-spaces between them. If the trees are large they should be tied to a strong stake to prevent their being blown about by the wind.

Large trees are sometimes successfully moved in the winter because a large ball of frozen earth may be taken up with the tree. Before the ground freezes in November, dig a trench about the tree deep enough to cut most of the roots. Fill the trench with straw and, when the ground is frozen, move the tree with the large ball of earth to the hole previously dug to receive it.

Evergreens should be transplanted early in the spring when the ground is moist.

HOW TO PLANT.

Distance Apart.-On rich, loamy soils the large trees used for street planting should be placed forty feet apart. In dry, stony, or sandy soil, twenty-five or thirty feet is far enough. The smaller trees may be planted closer.

Digging the Holes.-The hole should be dug large enough to take the roots of the tree without crowding, and deep enough to allow the tree to set a little deeper than it was before. Loosen up the sub-soil in the bottom of the hole and put in some fine, rich top soil before putting in the tree.

Planting.-Great precaution should be taken to prevent the roots of the tree from becoming dry while planting. If they are received sometime in advance of planting, unpack them and "heel" them in, i. e., bury, the roots in earth until ready to plant. When the cells in the roots of the tree have once become dry, it is very difficult for them to absorb water from the soil and start the current upward which supplies the leaves and growing shoots.

Cut off all the injured and broken parts of roots with a sharp knife. If a smooth cut is made, a callus forms readily, and above it are produced the fine, fibrous fecding roots.

One perscn may hold the tree in an upright position while another 
fills in rich top soil around the roots, being careful to work the soil well in among them and under the butt of the tree. The soil should be moist, but not wet, and free from large stones. Tread the earth or firm it with a rammer as soon as there is two or three inches of soil over the roots, so that there will be no air spaces about them; if there are air spaces the roots will dry out and the tree will die. Never put stable manure into the holes, as it causes clrying out. If the soil is very dry, water may be put into the hole after the roots are covered, and allowed to soak away before the rest of the soil is put in.

After the hole is filled, the ground about the tree should be covered with a mulch of straw or coarse stable manure. This will prevent the soil from baking or drying out.

Pruning.-After planting the tree, its top should be trimmed back in order that it may develop symmetrically and to counterbalance the loss suffered by the roots. It is better to cut back the side-branches than to cut off the entire top of the tree. The pruning should be done with pruning shears or a sharp knife, which will leave a smooth surface and not injure the bark.

HOW THE TREE GROWS.

When once well planted in a favorable location, the tree is generally able to supply itself with the necessary food and to maintain itself by growth. Some of the more important phases of growth may be mentioned.

Absorption of Water.-The greater part of the supply of water is obtained through the roots from the soil. It is not the large, woody roots which absorb the water, but the fine, fibrous roots. The fine young roots are covered with root hairs which readily absorb water through their thin walls and pass it upward to the tree through the larger roots. The precautions against drying while transplanting are necessitated by the delicate structure of these small roots, because they readily lose water through their thin walls when exposed to clry air.

A good mulch of straw or coarse stable manure is usually sufficient to keep the ground moist during the summer. In extremely dry weather, however, the tree should be watered and the ground under the mulch kept loose by stirring it from time to time with a hoe. If there is a heavy sod about the base of the tree, it should be cut away, and some lengths of drain tile be put vertically into the ground several feet from the tree. The water may be advantageously supplied through these tiles; merely watering the turf does not usually help the tree.

Transpiration, or the Giving up of Water Through the Leaves.The water which is taken up by the roots rises through the trunk ancl 
passes to the leaves and young growing branches. Most of it passes off in the form of vapor from the leaves, but a part of it is used in building up the substance of the tree.

The ascending current of water rises through the wood of the trunk. (Fig. I.) The causes of the upward flow are not fully understood, but in a general way it may be said to be accelerated by rapid evaporation from the leaves. Therefore, more water will be given off on a dry, windy day than in moist, still weather. The water vapor passes out through small pores in the epidermis of the leaves. Large trees undoubtedly give off as much as thirty to fifty gallons of water a day in dry weather.

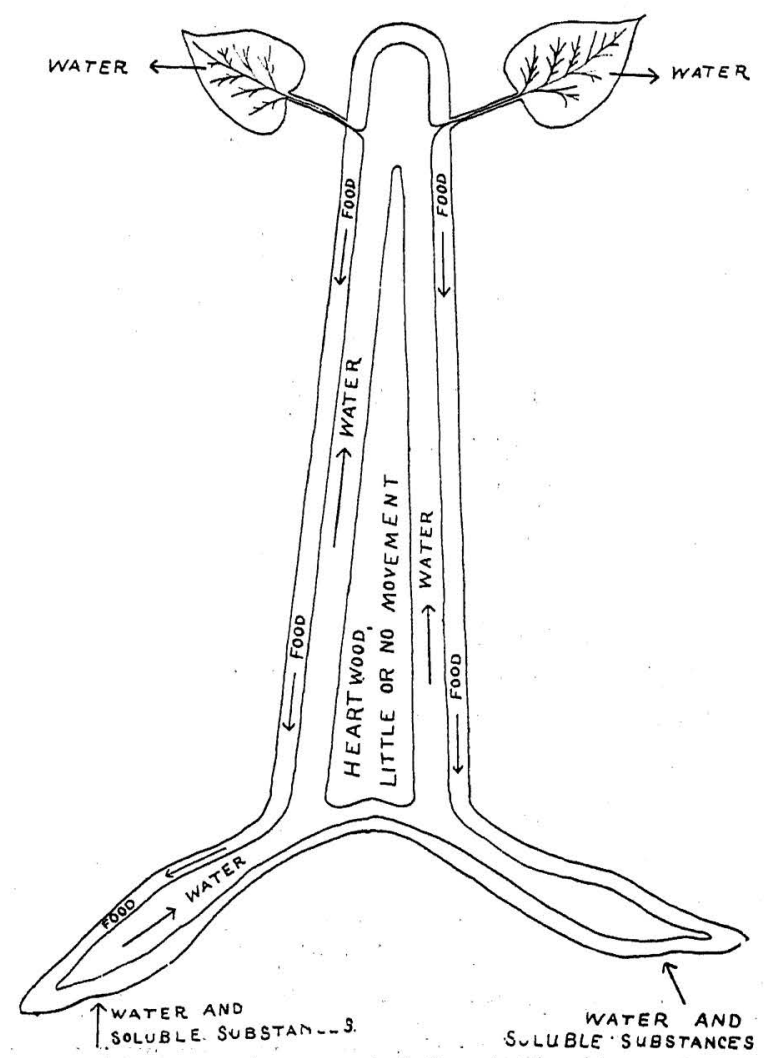

Fig. 1. Diagram of the structure of a tree, showing the path of the ascending and descending currents.

The advantage of this stream which enters the roots and passes out through the leaves lies in the fact that it brings in dissolved minerals from the soil and gives the plant a chance to use them in the manufacture of new materials.

Assimilation.-When wood is burned we see that a large part of it is composed of carbon. The tree obtained this carbon from the carbon- 
dioxide of the atmosphere. The most active agents in the transformation of carbon are in the cells of the green leaves. Air containing carbondioxide enters through the same pores from which water vapor escapes and, under the influence of light, the green coloring matter of the leaf takes it up and forms more complex carbon compounds from it, such as starch, sugars, gums, etc.

These considerations show us two important requirements for the growth of the tree, viz., leaves and light. Without the former the tree would be unable to obtain sufficient carbon-dioxide or to keep a stream of water passing upward through the body of the tree. Without the latter the process of food-formation in the leaves could not go on.

What practical bearing have these facts? They teach us that the leafdestroying fungi and insects should be kept in check; that trees should be planted far enough apart to allow the access of light; and that by proper pruning light and air should be admitted to the interior of the tree top.

These newly formed food substances do not remain in the leaf, but are transferred to the regions where growth is going on, or to special organs for storage. The paths through which this food material is transported lie in that part of the trunk known as the bast, or "inside bark." (Fig. I.)

When a tree trunk is gircled the downward flow is stopped at the place where the soft "inside bark" is removed. The tree does not immediately die, but in time, as a result of depriving the roots of their food, it does die.

Growth.-The growth of the tree does not occur alike in all parts, but is limited to certain tissues, viz., the so-called meristematic tissues.

The growing tissue of the trunk is confined to a few layers of delicate cells, between the bast and the wood, known to botanists as the cambiums. The increase in diameter is due to the division and growth of the cells in this layer. The food they need is in part furnished by the dissolved minerals absorbed by the roots and in part by organic substances manufactured in the green parts of the tree. These substances are absorbed by the cells of the cambium layer and used in the formation of new cells and cell products. When first formed, the cambium cells have thin walls, but as they grow older they become thickened by the addition of successive layers of cellulose. Later the walls undergo chemical changes and become infiltrated with various minerals and gums. They are no longer cambium cells, but are wood cells.

The character of the wood depends to a large extent upon the amount and kind of substances with which the walls are infiltrated. All the tissue 
arising from the inner side of the cambium ring goes to form wood, while that produced on the outside is the bast. The amount of wood produced is many times greater than the bast.

Owing to climatic variations, the cambium tissue of woody plants exhibits a periodical activity which results in the formation of annual rings of growth. In the spring, during the period of rapid growth, larger cells are produced than in the latter part of the season. For this reason, a difference is perceptible between the early zood, which is com-

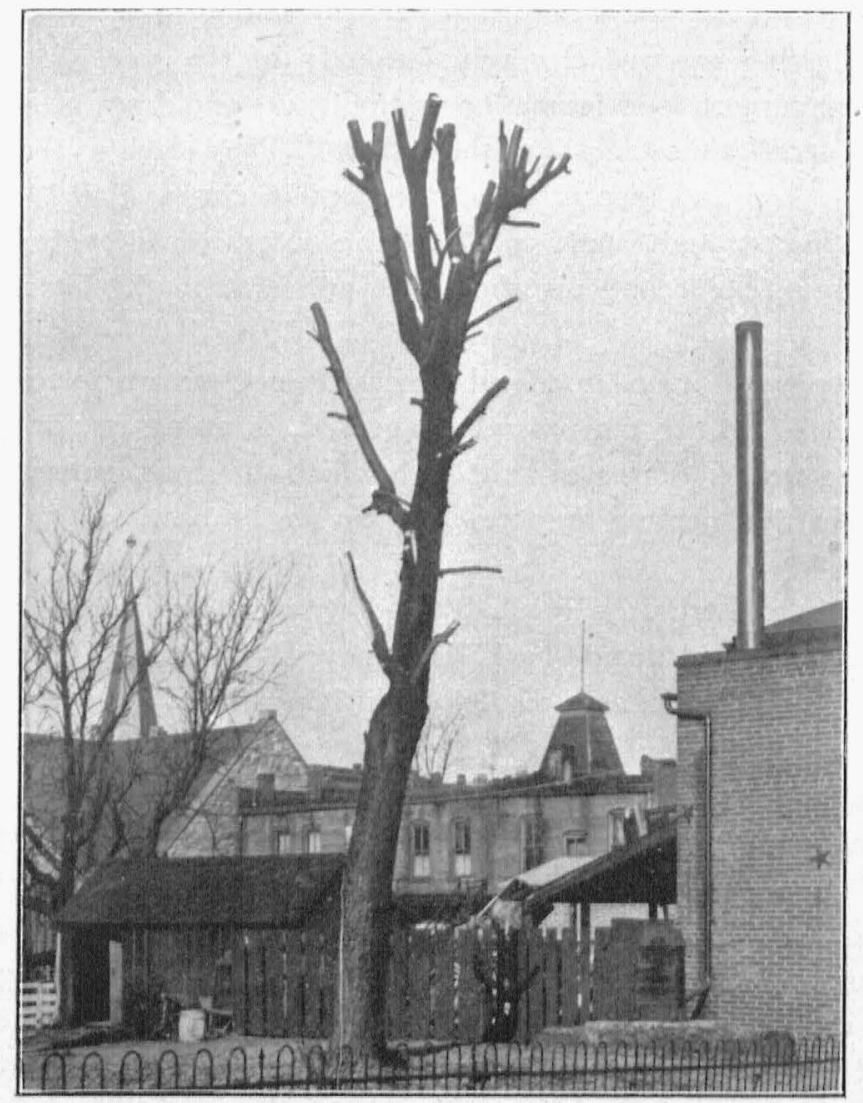

Fig. 2. A Silver Maple tree ruined by ignorant pruning. Notice the splitting of the stubs and the exposed wood. Photographed in December.

posed of large cells especially active in the conveyance of water, and the late wood, consisting of narrow cells which impart strength to the stem.

Throughout the greater part of the temperate zone, the formation of wood ceases in the latter part of August, until the following spring, when the larger elements of the early wood are again developed. The consequent contrast in the structure of the early and late wood marks off the 
growth into annual rings, which serve as a means of computing the age of a tree. Serious injury to the tree often follows the death of the cambium cells, which may be caused in a number of ways, e. g., by heavy objects striking the tree, by driving nails into the tree, the action of wooddestroying fungi, etc.

The Leaf-fall and the Winter Rest.-During the months of autumn, the leaves of our broad-leaved trees fall off, and during the winter months the trees are in a dormant condition. The leaves of the Evergreens assume a darker color and suspend activity, although they still remain on the tree.

What causes the fall of the leaf? Frost plays some part, but it is not the only cause. Early in the autumn a layer of cork cells containing

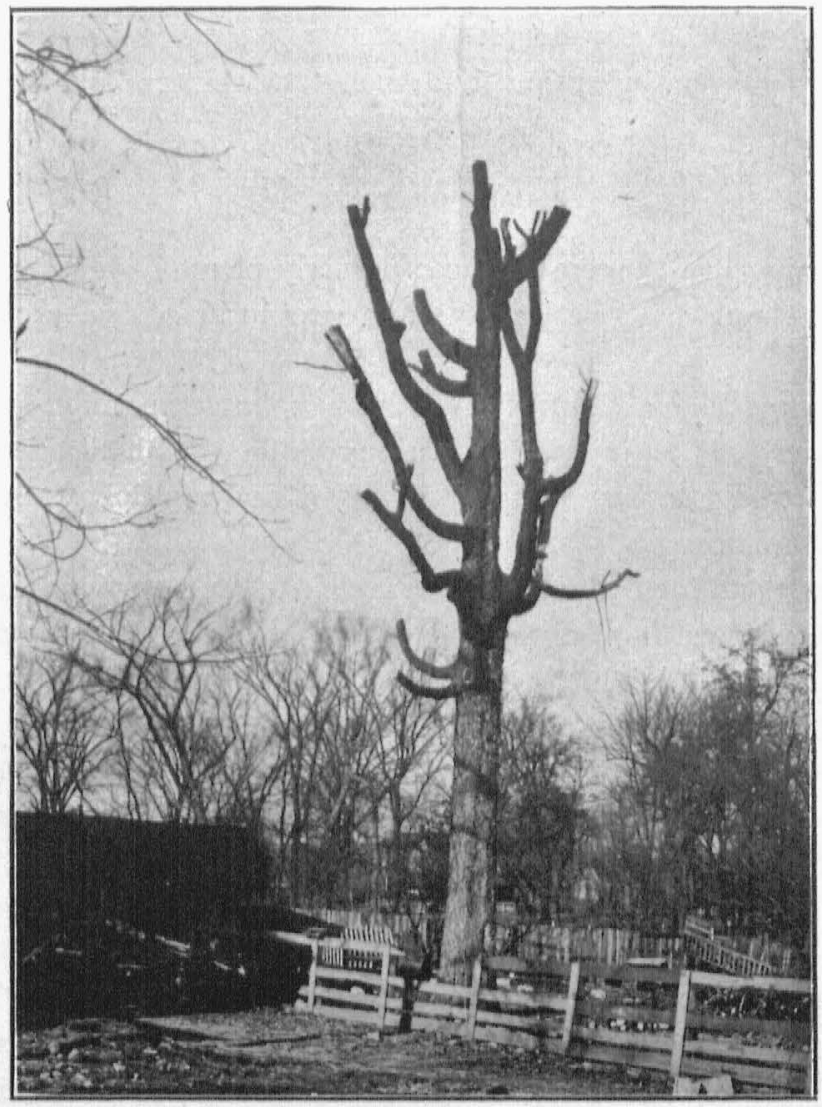

Fig. 3. An Oak showing the results of ignorant pruning. This tree will be inevitably attacked by a host of fungous and insect enemies. Photographed in December.

water is formed at the base of each leaf-stalk. When the water in these cells freezes, it tears apart the cell walls and allows the leaf to fall. If 
it is not frozen, the cells separate, as the protoplasm in them dies and the leaf dries out. The corky layer left protects the stem from injury by drying out, or by the entrance of rain and sleet during the winter. In this way the tree is covered naturally with a water-proof, corky layer during the dormant season, which allows but little loss of water.

Wounds which expose large surfaces to the air at the time the tree is dormant make severe drains upon the water content of the tree. It is unable to make up the loss of water by new supplies from the roots and consequently suffers damage.

The trees shown in figures 2 and 3 are in the worst possible shape for enduring the winter. Not only are the beauty and symmetry of the trees completely ruined, but the large exposed surfaces will allow serious loss of water while the tree is in a condition least able to withstand it. In cases where it is necessary to make large cuts (which are rare) it should be done in the spring, and then the wound should be painted over.

CARE OF TREES.

Assuming that the tree has been properly planted, we may now consider what should be done from year to year to keep it in growing condition.

Protection Against Injuries.-All trees, but especially street shade trees, are exposed to injuries of various kinds. With the development of our cities and towns, the adverse conditions multiply from year to year.

Excavations for buildings, sewers, etc., destroy portions of the root system, thereby cutting off the food supply. The street pavements and sidewalks are well-nigh impervious to water and hence diminish the supply of moisture in the soil on which they lie.

Unless proper precautions are taken, street trees suffer badly from having the bark gnawed off by horses. As has been shown, this destroys some of the most important tissues in the tree. The trees may be protected by a wrapping of burlap, tied on with tarred rope, but a substantial iron or wooden frame (Figs. 4 and 5 ) is better, because the burlap makes a breeding place for injurious insects.

The mulch should be removed from the base of the tree at the approach of winter, because it is likely to become inhabitated by mice, which girdle the trees when food is scarce in winter. If other rodents become troublesome, the bases of the trees should be enclosed with a guard of wire screen eighteen inches high, or the trunks may be painted with a lime wash made rather thick and containing one tablespoonful of Paris green 
to a pailful of the wash. If the wash is made up with skimmed milk instead of water it adheres better.

The most serious injury from insects and their larvae is done to the foliage. With trees on the street or lawn, the easiest method is to clip off

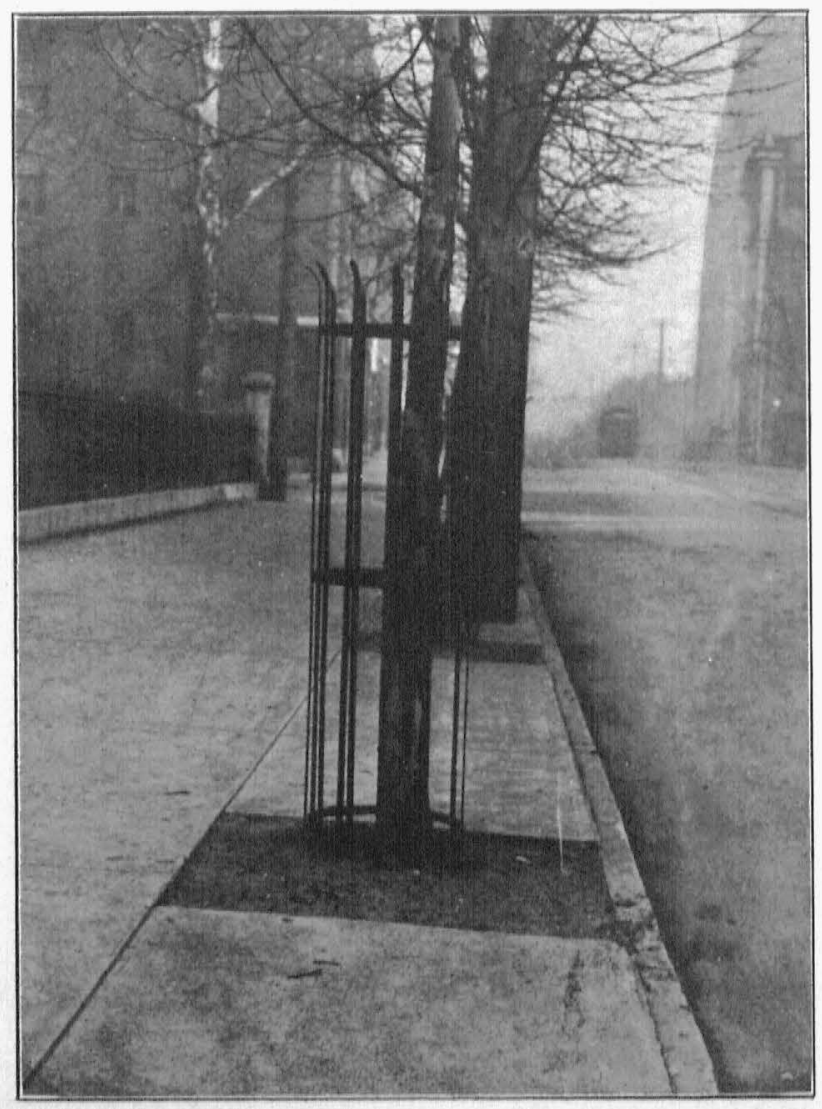

Fig. 4. Protection for street trees.

and burn the twigs on which the insects appear. Where large plantations are involved, the foliage may be sprayed with Paris green, applied by means of a force pump and spraying nozzle.

Larvae which crawl up the trunks of trees may be trapped by the following means: Wind a strip of thick cotton batting six or eight inches wide around the trunk just below the lowest branches, tie it with a strong cord at the lower edge of the strip. Now turn the strip down over the cord, forming an umbrella-like obstruction to any crawling organism. If desired, the inside of the obstruction may be smeared with coal tar.

There are numerous diseases which injure shade trees, but, except 
in severe cases, preventive measures are the easiest and most effectual. Remove and burn all dead branches and diseased or dead trees. In this way the infectious sources of both fungi and insects are destroyed.

Sunscalds are quite frequent among street shade trees, because they are not close enough to shade their trunks. In ordr to prevent it, the trees may be wrapped with burlap or with rye straw. When trees are injured by sunscalds the loose bark should be cut away down to the live growth and the exposed wood painted over.

Sleet storms and winds frequently break down trees which have not bcen properly trimmed. The Silver Maple suffers damage from this source. If no large crotches are allowed to form in the trees they will

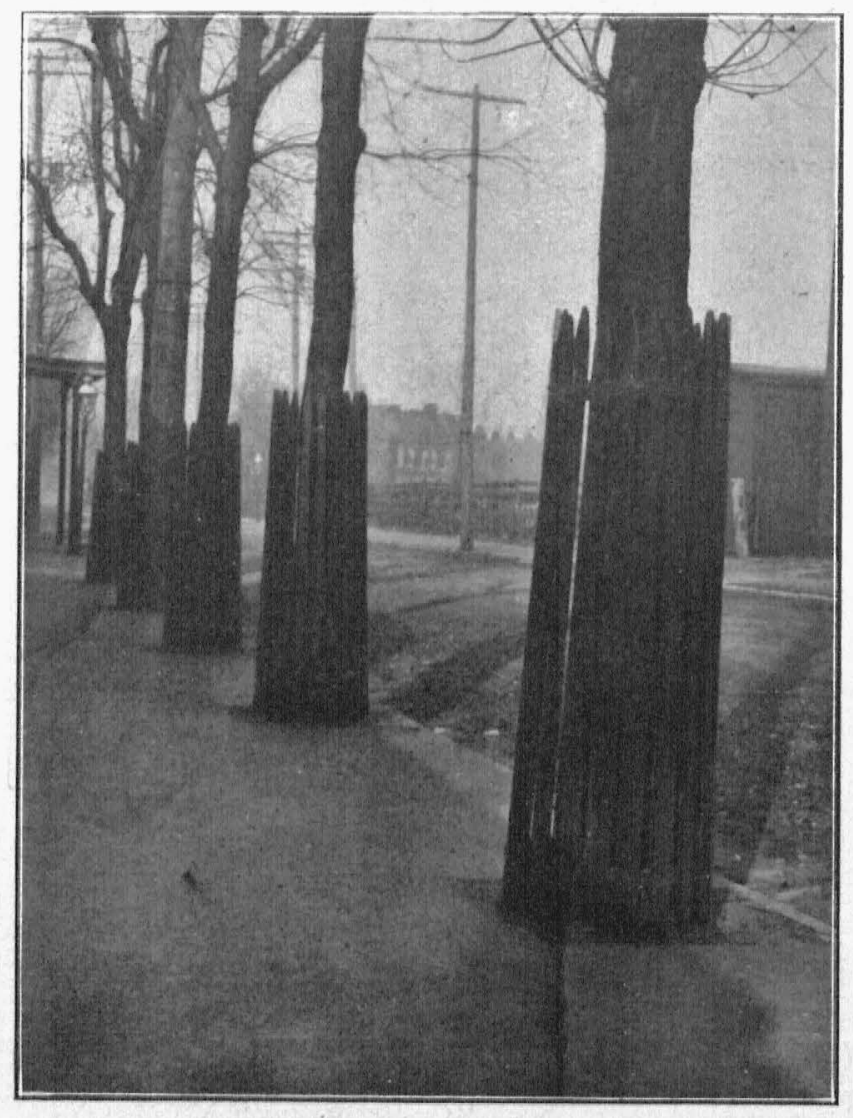

Fig. 5. Protection for street trees,

not be liable to injury. The method of pruning, shown in Figures 2 and 3 , cannot be recommended. Such trees had best be cut down, they are only valuable for cord-wood.

A moment's consideration of the structure of a tree, as briefly out- 
lined above, will show how severely it may be injured by having nails and staples driven into it. Not only are many of the delicate cells destroyed, but the holes formed admit sunlight, frost, and rain, each of which do their destructive work by killing the cambium cells in the vicinity of the wound. Figure 6 shows a tree which has been injured by a barbed wire.

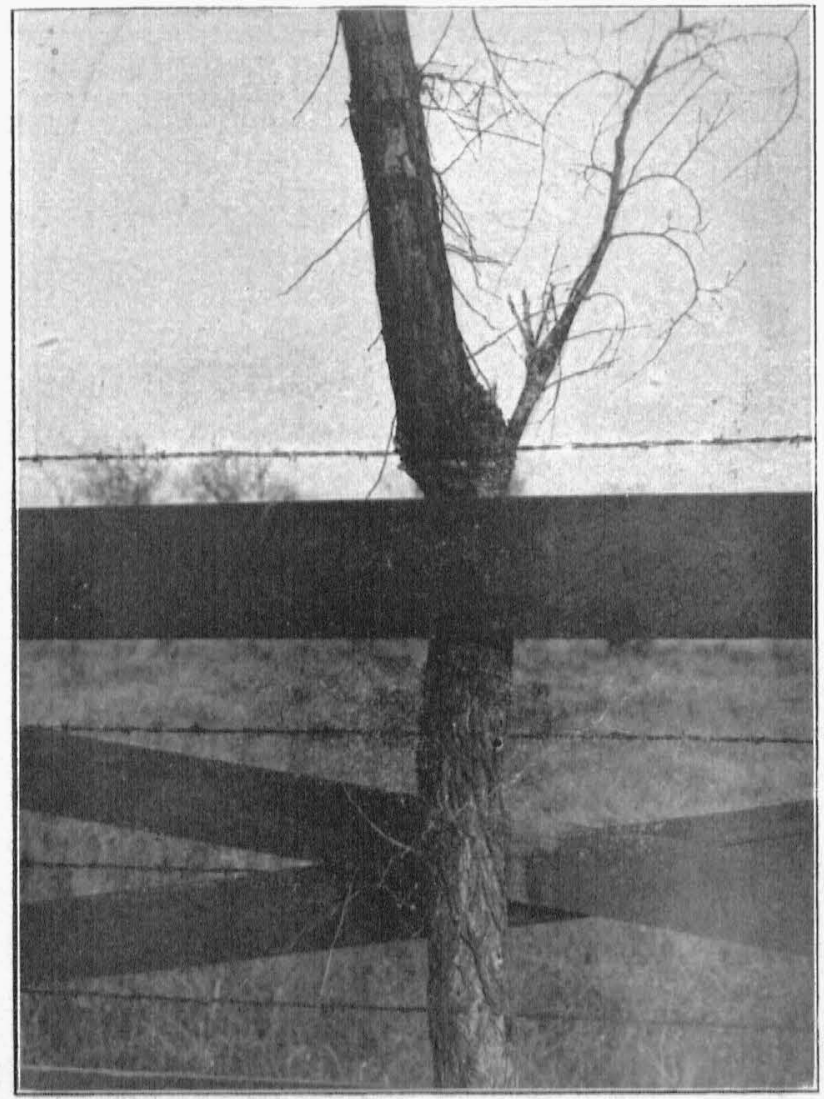

Eig. 6. Young EIm injured by barbed wire.

The increased number of telephone and electric wires in proximity to the branches of street trees is a serious menace to their welfare. Many. of the wires conducting currents for trolley lines and electric lights carry such heavy charges of electricity that they burn notches wherever they touch the trees. The damage is done in wet weather when the trees are covered with a film of water. ${ }^{2}$

In almost every town there are numbers of trees which have been in-

a For an admirable'study of this subject, see Bull. 91, Mass, Exp. Sta, 
jured or killed outright by electric wires, and the number increases annually. The time will come when either the trees or the wires must give way. The best solution of the difficulty is to bury the wires in conduits, as is now done in many cities; if this cannot be done they should be located in alleys, in the rear of buildings instead of the streets.

Trees are frequently mutilated to an outrageous extent by linesmen when erecting poles and wires. Figure 7 shows a sample of their

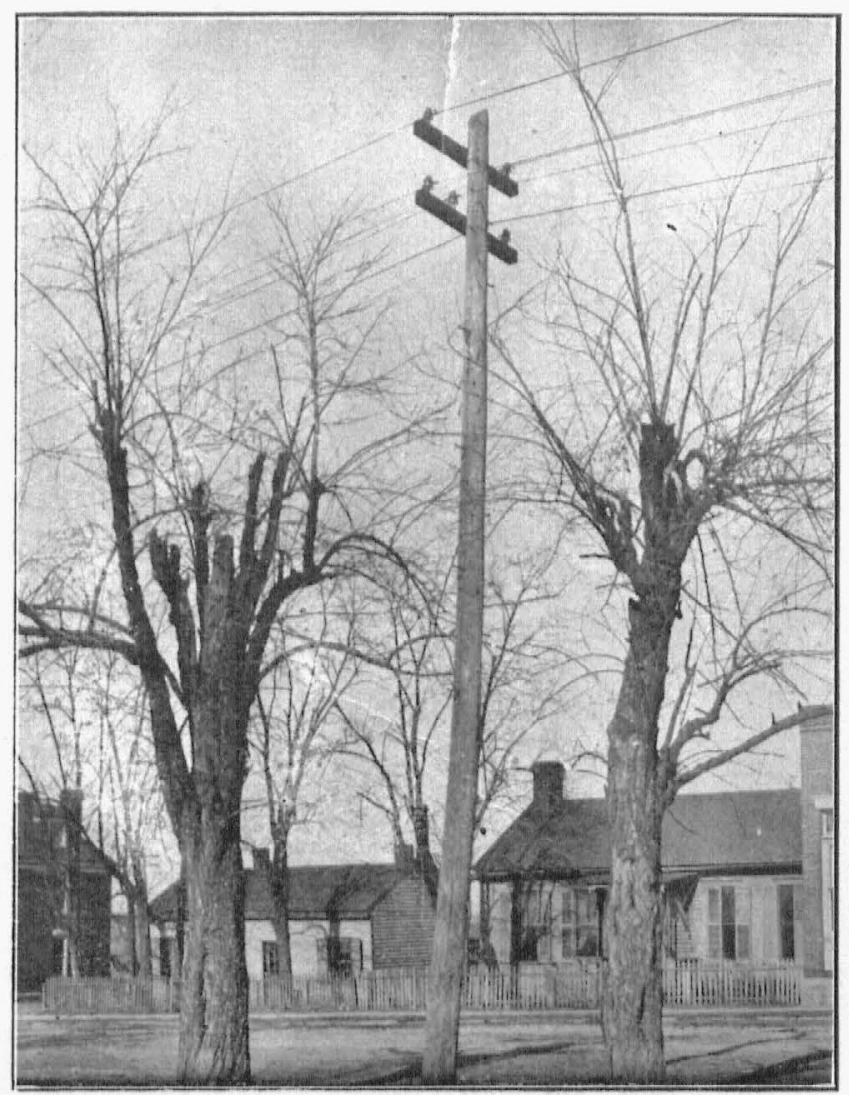

Fig. 7. Telephone poles vs, Shade trees. The destructive work of linesmen in erecting telephone wires.

destructive work. In this case the entire tops of the trees were destroyed, instead of merely a few branches, as is usually done. When we remember that it is the tall, erect trees which are most valuable as street trees, we see how futile it is to plant trees under a mass of wires. Both cannot occupy the same territory, we must choose the one we will have.

This is a matter which should not be neglected by town and city councils in granting franchises. Companies which have the privilege of erecting poles and wires should be strictly enjoined against injuring 
the shade trees by direct contact with high potential wires or by chopping off the branches.

When trees have become split at the crotches by storms, they may often be saved if the separated members be bolted together. The bolt is run through a hole bored through the separated branches and drawn up with a nut. Both the nut and the head of the bolt should be large, so that they will not draw into the wood.

Pruning.-At the time shade trees are set out, they should be carefully pruned, with a view of helping them to develop into symmetrical trees; after that a little pruning from year to year is all that is required. In the case of elms and trees which have been brought from the woods it is a good plan to cut them off about ten feet above ground and trim the side branches back to stubs. If the trees have well formed heads, they may be simply shortened in when transplanted.

The Silver Maple, like other soft wood trees, needs particular attention at this time. Preferably, it should be pruned to form a main central axis with numerous smaller secondary branches arising along the main axis. In cases where this cannot be done, the tree should be trained to form a symmetrical head, in which no large crotches are allowed to form. After the first few years street trees will need but little pruning: they should be examined each spring, however, to see what is necessary. Trees may be pruned about the time the buds start in the spring and from that time until they are in full leaf. During this time the growth is active and the wounds heal rapidly.

Some general principles of pruning for all trees may be suggested. If the tops of the trees are to be shortened in, it should be done gradually. No branch more than one inch in diameter should be cut off, but the heading in should be repeated from year to year, until the tree is of the desired shape. The practice of cutting off the larger limbs squarely at the top is very injurious, for reasons already noted. It should never be permitted.

When removing a branch, cut it close down at the shoulder with a sharp saw, so as to leave no stump. The adjoining cambium cells will then be able to grow over the wound and close it. In case the limb is over two or three inches in diameter, it should be cut off a foot or more from the base, to prevent it from splitting or peeling back the bark; then the stump should be cut off close up to the main trunk, leaving a smooth surface.

As soon as dry enough, all large cuts should be painted as directed below.

No street trees should be allowed to develop branches within eight feet of the ground, for the safety and convenience of pedestrians. 
Remove all dead branches and old stubs as close to the trunk as possible and paint the exposed wood.

Examine cracks and patches of dead bark to see whether the bark and wood have separated. If they have, cut away all the dead bark and paint the exposed wood.

If there are cavities in which the wood is badly decayed it should be dug out and a plug of sound wood fitted in and painted over.

Trees which are dead, or nearly so, should be removed, because they furnish breeding places for insects and harmful fungi. They no longer possess any beauty, but are a menace to all other trees in the neighborhood.

COATING FOR WOUNDS.

The most satisfactory coating for tree wounds is thick lead paint well rubbed into the wood.

Coal tar which has been burned until it is hard when cold is also good. It should be burned in a large kettle and applied when warm, but not hot, with a brush. 